\section{"A little monster inside me that comes \\ out now and again": endometriosis and pain in Austria}

\author{
"Um pequeno monstro dentro de mim que \\ sai de vez em quando": endometriose \\ e dor na Áustria
}

\section{"Un pequeño monstruo dentro de mí que sale una y otra vez": endometriosis y dolor en Austria}

Margret Jaeger 1

Manuela Gstoettner 2

Ines Fleischanderl 1

doi: 10.1590/0102-311X00226320

\begin{abstract}
The topics of endometriosis and pain imply far-reaching problems for women's health. Using a qualitative research approach, this paper addresses the subjective experience and effects of pain, the methods for dealing with these issues, and the needs of affected women in Austria. Data were collected by problemfocused interviews conducted with ten women suffering from endometriosis, which were later transcribed and subjected to qualitative content analysis. Findings are therefore described using content-related categories. Results show that negative thoughts and feelings like fear, despair, and anger are associated with endometriosis and pain. Moreover, predominantly negative impacts and changes are found in various areas of life, such as the well-being and psyche of those affected, their attitude towards life in general, partnerships, social life, leisure time and work-life balance. In dealing with endometriosis and pain, both Western biomedicine and complementary medicine treatments are used. Support from one's inner circle of friends and exchange and interaction with others affected by the disease are seen to be invaluable. Attending physicians as well as patients themselves and their private, social, and working environment should encourage open communication about endometriosis and the related pain.
\end{abstract}

Endometriosis; Pain; Qualitative Research

\section{Jaeger}

Sigmund Freud University.

Adalbert-Stifter-Platz 2, 4020 Linz / Oberoesterreich, Austria.

margretjaeger@yahoo.com

1 Sigmund Freud University, Linz, Austria.

2 Medical University of Vienna, Vienna, Austria. 


\section{Introduction}

Endometriosis is a chronic, benign, and estrogen-dependent disease in which endometrium grows outside the uterus 1 that affects around $10-15 \%$ of all women of reproductive age, resulting in around 176 million women worldwide 2 . To date, recovery is not possible and pain is a major symptom, which considerably reduces the quality of life of affected women. This paper addresses the pain perceived by women in Austria and their experiences regarding diagnosis and coping strategies for this condition.

The scientific literature includes several qualitative studies on the pain experienced by women with endometriosis $3,4,5,6$, showing that these women are often restricted in their private, social, or occupational lives by this condition 3,4,7,8,9. In Austria, however, detailed qualitative research on how women experience pain caused by endometriosis and which coping strategies they use has yet to be published.

Our study, therefore, sought to understand the experience and effects of pain, the methods for coping with these issues, and the needs of selected endometriosis patients in Austria. Information about the individual stressors and effects of pain caused by endometriosis is thus of importance here. Given these objectives, we used a qualitative study design and data evaluation based on qualitative content analysis to address the individual experiences and coping strategies of women 10.

\section{Theoretical framework}

Several are the theories on the cause of endometriosis. The most often cited, that of implantation (retrograde menstruation), proposes that during menstruation the endometrial tissue is carried backwards through the fallopian tubes, continuing into the peritoneum or the organs of the lower pelvis. The phenomenon of retrograde menstruation, however, is physiological in most women, and by itself does not support Sampson's theory elaborated in the 1920s. Another theory argues that endometriosis can develop via metaplasia of cells and thus arise in locations outside the pelvis 11 . Others debate whether the disease is caused by the transport of fragments of the uterine lining via lymph vessels 12 . The immune system may be another important aspect, as insufficient immune monitoring and malfunctioning cellular immunity in the peritoneum could cause the condition 13 .

Genetic/hereditary components are considered a risk factor for the occurrence of endometriosis. The risk of developing endometriosis is particularly present in first-degree relatives of patients with severe endometriosis and is about seven times higher than the risk of relatives of women not affected by this disease 14,15 .

Pain associated with endometriosis is difficult to understand 16. Patients can suffer from severe dysmenorrhea, dyschezia, dyspareunia, dysuria, chronic pelvic pain and or sterility - which leads to a reduced quality of life, particularly due to pain, but also due to unwanted infertility 17 . Defined as "an unpleasant sensory and emotional experience associated with actual or potential tissue damage or described in terms of such damage" 18, pain is essentially divided into acute (to a maximum of three to six months) and chronic properties 19,20. The long-lasting effects of chronic pain can be as oppressive, burdensome, and limiting as the original pain itself 21. Moreover, chronic pain in the lower abdomen is a cardinal symptom of endometriosis, resulting in fearful expectations. This vicious circle consequently leads to increased tension and intensified pain 22.

Unspecified compromising secondary symptoms, such as headaches and pain near ovulation, or pain radiating to the legs, can also occur 23 . Pain also impacts quality of life in many respects. Due to severe pain, for example, women experience physical discomfort and increased fatigue, which have a negative influence on their social lives 4,6,24.

In Germany and Austria, an average of 10.4 years elapses between the occurrence of the first symptoms and diagnosis 25 . Conversely, in the US and Great Britain an average of 11.7 years elapses until diagnosis, and 6.7 years in Norway 26,27. In Brazil, while one study showed a period of only 3,8 years until diagnosis 28 , a 2018 research found a delay of 12 years until diagnosis 29 . A multicenter, cross-country study by the Global Study of Women's Health (GSWH) showed a time range from 4 to 10 years 30 . 
Women often report that they had never heard of endometriosis before receiving the diagnosis 31 . Unfortunately, physicians are not always familiar with this disease either. This leads to deficits in terms of diagnosis, a lack of knowledge about endometriosis, and patients not being taken seriously 32 .

Treatment can involve surgery and medication (analgesic or hormone therapy), whereby two different goals are pursued: reducing the symptoms associated with endometriosis and resolving infertility 33 . Besides these forms of therapy, physiotherapy 34 , complementary therapies 35 , nutritional 36,37 and psychological 38 counseling can also be used. The best therapeutic approach for endometriosis should be individually tailored to each patient, depending on their situation 39 .

\section{Methodology}

Data were collected by problem-focused interviews 40 with an open guideline 41 designed based on existing studies and aimed at gathering specific information on pain management. As the interviews focus on experiences and events, we chose a qualitative approach 42 .

The target group consisted of women between the ages of 18 and 55 diagnosed with endometriosis and living in the federal regions of Upper and Lower Austria. Participants were invited via a call for potential interview partners on the Facebook page of the Endometriosis Association Austria (EVA) 43 and by an announcement on the personal Facebook page of I. Fleischanderl, author of the master's thesis. Snowball sampling, which is directed towards the available relationships in the research field, was also used 44. Ten women between 22 and 51 years of age, for whom the symptom of pain caused and still causes them the most discomfort, responded to the call.

The interviews took place between 27 February and 26 March, 2019 and lasted between 50 and 75 minutes. Participants answered a brief sociodemographic survey (Box 1) followed by a semistructured interview. The collected data was then transcribed according to standard orthography 41 and subjected to qualitative content analysis and category-led text analysis. Category formation was carried out both deductively and inductively. First we established which material would be analyzed, and then laid down the formal characteristics of the collected data. Results were interpreted using qualitative content analysis 10 . Summarizing and explicating content analysis were used throughout this study. As the research was originally done in German, all citations were translated into English and spell-checked by a professional translator.

Box 1

Sociodemographic data of the interviewed women.

\begin{tabular}{|l|c|c|c|c|c|}
\hline PARTICIPANT & $\begin{array}{c}\text { AGE AT DIAGNOSIS } \\
\text { (YEARS) }\end{array}$ & $\begin{array}{c}\text { CURRENT AGE } \\
\text { (YEARS) }\end{array}$ & $\begin{array}{c}\text { MARITAL } \\
\text { STATUS }\end{array}$ & $\begin{array}{c}\text { CHILDREN } \\
\text { (MORE) CHILDREN }\end{array}$ & No \\
\hline P1 & 20 & 31 & Married & 2 & Yes \\
\hline P2 & 23 & 25 & Partnership & 1 & No Head Secretary \\
\hline P3 & 30 & 44 & Married & 2 & Organization and management \\
in the social sector & Student with part-time job \\
\hline P4 & 23 & 24 & Single & 0 & Fashion advisor \\
\hline P5 & 30 & 41 & Married & 0 & No \\
\hline P6 & 19 & 22 & Partnership & 0 & Yes \\
\hline P7 & 30 & 37 & Partnership & 0 & No \\
\hline P8 & 24 & 28 & Married & 2 & Student with part-time job \\
\hline P10 & 22 & 25 & Single & 0 & No \\
\hline
\end{tabular}


Interviewees were informed orally and in writing about their participation and signed an informed consent form. In this paper, they are presented anonymously, using codes (P1, P2, etc.).

As the women were interviewed as affected persons and not as patients, and outside of a health care institution, the province's legal provisions province and university regulations did not require approval by an Ethics Committee. But being aware of the sensitivity of the issue, the researchers pointed out to interviewees the support opportunities provided by the EVA 43 . The audio recordings were deleted after transcription and the transcripts will be stored on a secure server of Sigmund Freud Universtiy (Linz, Austria) for ten years in compliance with the European Union's General Data Protection Regulation 45.

\section{Results}

Our results represent the experiences and feelings of ten women from Upper and Lower Austria. The sample had an average age of 32.8 years, duration from symptom onset until diagnosis ranged from 2.5 months to over ten years, and the average age at diagnosis was 25.6 years (Box 1).

Qualitative content analysis 10 resulted in eight categories including sub-categories formed, of which categories 1 (endometriosis), 2 (pain), 4 (dealing with endometriosis and pain) and 6 (wants and expectations) are relevant for the present discussion (Box 2). The remaining four categories go beyond the scope of this article, so they are not described in this results section.

\section{Endometriosis - "a little monster"}

The following statements cover the women's descriptions of the disease and how they experienced diagnosis and the time immediately afterwards.

Some interviewees stated that endometriosis was like a "shadow", "a little monster" or a "wake-up call", while others found it difficult to provide an individual description of the disease. All the women claimed that their symptoms were dependent on their menstrual cycle. P2 also stated experiencing pain unrelated to the menstrual cycle. None of the women interviewed had heard of endometriosis prior to diagnosis or had affected relatives. Two women said they learned of other endometriosis patients among their social contacts after diagnosis.

None of the respondents were able to explain in detail the disease and its causes, but all had read about the theories on its origins. The time elapsed before diagnosis was described as an ordeal on several occasions. Despite having the symptoms for several years, endometriosis had not been suspected and diagnosed: "Initially I thought it was quite normal. There are so many women who have problems with menstruation" (P6), "I always somehow knew that it isn't the way it should be. But nothing was done about it" (P7).

Box 2

Categories found by qualitative content analysis.

\begin{tabular}{|l|c|}
\hline CATEGORY & CONTENT ANALYSIS \\
\hline Category 1 & Endometriosis - “a little monster" \\
\hline Category 2 & Pain - “detrimental to life" \\
\hline Category 3 & Thoughts and feelings regarding endometriosis and pain - "why?" \\
\hline Category 4 & Coping with endometriosis and pain - "stay calm" \\
\hline Category 5 & Effects and changes caused by endometriosis and pain - "quality of life" \\
\hline Category 6 & Wishes and expectations of the women affected - "communication" \\
\hline Category 7 & Taboos - "don't talk about it" \\
\hline Category 8 & Talking about it - "contact with others in the same position" \\
\hline
\end{tabular}


The women's own physicians were often puzzled and had no idea what the problem could be. Explanations of symptoms were often ignored, and the women therefore felt that they were not being taken seriously: "Well, as a doctor, if you can't explain something you look for a psychological reason. That was the worst thing. I never heard anything about endometriosis from a specialist at that time. No suspicion of it, nothing at all. Just that period pain is normal, and you'll have to grit your teeth and get over with it, or you can go to a psychologist and see if something else is not right" (P1).

After diagnosis, the women's social circle reacted with questions and a certain skepticism. All respondents had the impression that very few people could believe or understand the pain they were suffering. Six participants particularly emphasized the lack of understanding among men: "I think it's very gendered because women can understand it much better than men. I noticed that among my friends, at work, and within my family" (P4).

As a result of this trivialization of their symptoms, some women started to doubt themselves and to question their perceptions, sensations, and behavior. Nevertheless, interviewees also mentioned positive experiences. The most important people in their social circles often reacted with empathy, were considerate and understanding - most certainly because after diagnosis, the participants could better explain their situation and make themselves understood.

\section{Pain - "life-impairing"}

This category summarizes the experiences of pain of the affected women. As discussed, the range of pain symptoms in endometriosis is diverse. In our sample, it ranged from pain in the lower abdomen to headaches and leg pain, with the women rating the severe pain between 6 and $10(0=$ no pain to 10 = unbearable pain): "Well, more than ten. In bed, I would often think: if it gets any worse, I've had it. Sometimes I was close to becoming unconscious" (P5).

Six interviewees stated that while they were generally paint resistant and tolerate high levels of pain well without painkillers, with endometriosis they frequently reached their pain barrier. Participants described the endometriosis-induced pain as "spasmodic, sharp, aching, burning or like labor pain, dull, wearing, extremely strong, unpleasant and life-impairing”. Some respondents offered graphic or metaphorical descriptions of their pain: "Once I described it as being like someone shoving knitting needles up your backside. (...) It was really like someone shoving something up your backside. The pain is really, really bad" (P1), "It's like someone rammed a curved sword with a serrated blade in you and then twist it twice" (P7).

Three women reported becoming unconscious while away from home. Limitations on their social lives due to being unable to move because of the pain were also frequently mentioned: "We were going for a walk one day and then - I must have walked for about five minutes and then I couldn't walk any further because of this stabbing pain, then I had to vomit. Then we drove to the hospital" (P6).

Two women added distress as an influencing factor on the occurrence and intensity of pain.

\section{Dealing with endometriosis and pain - "stay calm"}

This section summarizes different treatment methods and coping strategies reported by the interviewees. Aspects that proved helpful and conducive to coping with endometriosis at an individual level are highlighted here.

Those affected informed themselves about treatment methods mainly by consulting gynecologists or searching the Internet. One woman, however, advocated against Internet research, as she found upsetting information or exaggerated descriptions. Results reveal that participants predominantly view antispasmodic or analgesic medications and various hormonal medications as helpful and effective as mainstream medical treatment options.

Of the ten interviewees, nine had already undergone a laparoscopy. Of these, five said that their symptoms improved after the surgery and removal of endometriosis lesions; two women stated that the laparoscopy had not led to any reduction in pain; and two could not give a clear answer. One also reported that symptoms had returned after the operation.

The participants' experiences with conventional medicine varied. Before diagnosis, they had fewer positive experiences. Despite the physicians' willingness to help, their ignorance concerning the symptoms meant they were not of much assistance to their patients. Four women said that instead of 
finding and treating the cause, priority was given to treating the symptoms: "Previously, when no-one knew what was going on, I kept having the same experience, they kept giving me antibiotics, which might be a solution for now, but do not solve the problem (...) Well, mainstream medicine is all well and good, but in this case, it was pretty useless" (P2).

Conversely, some participants also reported positive and neutral attitudes and opinions. One interviewee posited that it takes time to find the right solution for each person. Another said that she was satisfied with her gynecologist and with the treatment that had been initiated.

Only a few of the participants took advantage of alternatives to mainstream medicine. Those who had useful experiences mentioned the following additional methods as beneficial to their symptoms: acupuncture, agnus castus tincture, turmeric capsules, hemp, and aromatherapy.

Exercise, weight loss, sleep, relaxation, warmth, and taking time for oneself and talking to a friend about the situation are additional elements that have helped women reduce pain.

Two women received nutrition tips from their gynecologist; another two discovered this relationship by themselves. Physiotherapy was recommended to one of the women by a gynecologist - which she reported as a positive experience.

Although only one woman underwent discussion therapy, all interviewees pointed out that counseling was important and effective for women who cannot find a way to cope with endometriosis and pain without professional help.

All of the participants asserted that accepting the diagnosis of endometriosis played a role in dealing with pain and helped them cope with and master the situation. Having a clear diagnosis could even be a decisive factor in being able to accept the situation more easily.

The women received support from their families, friends, or other women with the same diagnosis, which they characterized as being mainly consideration, understanding, and encouragement. But the interviews also revealed that some women deal alone with issues related to endometriosis and pain and withdraw, with those around them often being unaware of their symptoms. Some would also like more support and help from their families.

\section{Wishes and expectations of the women affected - "communication"}

This final category summarizes the women's wants and expectations regarding the healthcare system and their environment.

They expressed a desire to be taken seriously, to get more understanding, recognition, and acceptance, and to have their pain not be trivialized. They also wished that people would not theorize about their chances of having children, and wanted there to be a treatment that could lead to a full recovery. The participants would also like the medical staff to be better informed about postoperative developments and be able to explain the disease better. They want physicians to place importance on recognizing illnesses and being able to explain them to patients. The women also expressed their desire for physicians to look for the causes and perform accurate examinations. They want to be seen from a holistic perspective and would like mainstream and alternative approaches to be merged.

More cooperation between the fields of medicine and therapy/psychology was also reported as desirable. A point of contact for women affected by endometriosis was the desire for communication to be optimized and for evidence-based patient information to be passed on. Women also want endometriosis to be discussed more openly, and for the general public to be provided with more information about it, and for the disease to be recognized and seen as "legitimate". The menstrual cycle should generally receive more attention. Finally, their desire not to be judged simply for being women should be highlighted: "Pain is a subjective thing. It should not be belittled. That's not right. It must always be taken seriously. It has to be scaled. Somehow it has to be tangible for everyone involved as well. Regardless of whether you are the one seeking help, or the one who wants to help" (P1); "And I think there should be a lot more communication about it - about the issue. I know there is a World Endometriosis Day, but I think hardly anyone knows that it exists. Unless someone posts something on Facebook, you never hear anything about it. There's a lot more [people] talking about the World Childhood Cancer Day or whatever. There should also be a lot more public information about it" (P7). 


\section{Discussion}

A literature review showed that ours is the first qualitative study on pain in women affected by endometriosis in Austria. The interviews carried out with the ten participants revealed delays in diagnosis of over ten years, a finding that corroborates the average time of 10.4 years from the first symptoms to a correct diagnosis found in Austria and Germany 25. None of the respondents had heard of the disease prior to the diagnosis. A qualitative study in the Netherlands with general practitioners also showed that these professionals knew very little about the characteristics of endometriosis 46 . This interesting field of research has not received any attention in Austria so far, even though general practitioners are the first point of contact in health services. A literature review on these issues mentions the need for medical staff to have knowledge, empathy, and good communications strategies to be able to support suffering women in the best possible way and maintain good physician-patient relationships ${ }^{47}$. As early as 2015, women interviewed as part of a qualitative study in Styria (Austria) expressed their desire for improved communication with physicians 48 . In the case of nine women interviewed for a Swedish study, those who went to physicians who showed understanding for their symptoms accepted their diagnosis better and more quickly than those who experienced a lack of interest and disbelief 49 .

The social environment of the women interviewed also reacted somewhat skeptically to the disease, pointing to a general lack of information about endometriosis. This finding corroborates other studies done in 2014, in which women also reported that they had never heard of the disease before being diagnosed with it 31 . Thus, there appears to have been virtually no change in the level of awareness about endometriosis over the years.

We must also emphasize that the women's symptoms were minimized and not taken seriously by their doctors, their families, and their social and work environments, which led to doubt in their feelings and behavior regarding the symptoms. Other studies also highlight how the women's severe period pains and other symptoms were shrugged off as normal by their families, friends, colleagues or doctors, pointing out this minimization as the main reason for late diagnosis $31,35,50$. Our findings indicate that physicians in all fields should be educated about endometriosis so that they can promptly refer patients to specialists or a specialized center to investigate symptoms. The EVA website lists 16 endometriosis competence centers across the country that aim to increase the quality of treatment 43 . In this context, one should investigate the opinions of specialized medical staff.

The pain symptoms reported by the participants are quite wide-ranging. Individual descriptions of pain by the interviewees, their stories of significant experiences and pain, and their thoughts and feelings regarding endometriosis and the resulting pain also underline the broad spectrum of endometriosis-induced pain experienced by women. This finding is consistent with other results found in the literature 9 .

To record pain, medical science often asks patients to describe their perception of it 29,32,51. As the present study has shown, however, describing their pain is quite difficult for some: it is often heard that patients find it difficult to describe their pain in words. Difficulties in giving a description or deciding which adjective to use are common occurrences 52 . Diverse tools to measure the long-term effects of endometriosis on various aspects of life could help physicians when talking to women about the disease 53,54 . However, a comparative study of pain descriptions in a conversation with a physician and an interview in a non-clinical setting showed that the quality and general validity of the adjectives given in a pain questionnaire are limited, revealing the need for qualitative studies on this topic 52.

The interviews conducted showed that not only conventional approaches, but also alternative and complementary methods are used to cope with endometriosis and pain. In some cases, a combination of several treatment strategies also proved to be effective. Surprisingly, only one woman was recommended a dietary change by a physician. Studies have shown that a Mediterranean diet rich in vegetables and fish can have a positive effect on the symptoms of endometriosis 4,36,37. Despite the usefulness of physiotherapy in reducing pain ${ }^{34}$, only one woman was advised to do so - which she reported as a positive experience.

Our results show that endometriosis and pain lead to limitations in patients' social lives and leisure activities. For instance, women had to cancel meetings and could not participate in activities with friends because they had to consider their menstrual cycle. They were also limited in terms of 
sports activities. Other studies have also found a similar reduction in social, sports, and leisure activities 29,31,55,56. Importantly, while Austrian women did not report being left by their partners, Brazilian women reported ending relationships due to the disease 29.

Our results elucidate that women's attitudes towards life have changed, with interviewees reporting that they underwent positive personal development and have learned to cope with endometriosis and pain over time. One study showed similar findings, with women saying they found a way to cope and live with the disease 50. Accepting the diagnosis and having a positive attitude towards life and sense of humor played an essential role here. Since the subjective experience of pain and the effects of endometriosis are wide-ranging, diverse, and individual, affecting many areas of life, treatment must include psychological measures and support.

\section{Limitations}

As limitations of this study, we can cite the number of participants reached by snowball sampling, the participants' access to the Internet, and the one-month time frame for the survey. Also, the regional restriction of the study to Upper and Lower Austria cannot reflect the overall situation in Austria due to differences in access to endometriosis competence centers.

The search for participants had no restrictions regarding ethnicity, as ethnic diversity is part of the Austrian reality, and access to the health care system via statutory health insurance is - theoretically - the same for everyone. Although this study does not examine whether women of different ethnicities experience pain or endometriosis differently, such a topic could be explored in further research.

\section{Conclusion}

This study examined the subjective experience of women regarding endometriosis-induced pain. Results reveal a complex issue that includes a long period of suffering, a long time to a correct diagnosis, a lack of understanding by physicians and the women's social circle, a lack of knowledge, and a feeling of helplessness. Pain proved to be diverse (e.g., severe dysmenorrhea, dyschezia, dyspareunia, dysuria, chronic pelvic pain, back pain) and was described by different characteristics (e.g., stabbing, spasmodic, dull, aching). Getting a clear diagnosis helps women understand and accept their symptoms. These findings point to room for improvement regarding information on endometriosis, communication with affected women, pain management in general, and complementary methods for this disease. 


\section{Contributors}

M. Jaeger and M. Gstoettner contributed to the study design, data analysis, and manuscript writing. I. Fleischanderl contributed to the study design and data collection and analysis. All authors approved the final version of the manuscript.

\section{Additional informations}

ORCID: Margret Jaeger (0000-0003-0990-8181); Manuela Gstoettner (0000-0002-1714-0590); Ines Fleischanderl (0000-0001-8585-0140).

\section{Acknowledgments}

We would like to thank the anonymous reviewers for their comments to improve this article, Lucas Melo (São Paulo University at Riberão Preto, Brazil) and René Wenzl (Medical University of Vienna, Austria) for their comments, and our translator Mike Delaney for his efforts.

\section{References}

1. Simoens S, Dunselman G, Dirksen C, Hummelshoj L, Bokor A, Brandes I, et al. The burden of endometriosis: costs and quality of life of women with endometriosis and treated in referral centres. Hum Reprod 2012; 27:1292-9.

2. Marinho MCP, Magalhaes TF, Fernandes LFC, Augusto KL, Brilhante AVM, Bezerra LRPS. Quality of life in women with endometriosis: an integrative review. J Womens Health (Larchmt) 2018; 27:399-408.

3. Hållstam A, Stålnacke BM, Svensén C, Löfgren M. Living with painful endometriosis: a struggle for coherence. A qualitative study. Sex Reprod Healthc 2018; 17:97-102.

4. Huntington A, Gilmour JA. A life shaped by pain: women and endometriosis. J Clin Nurs 2005; 14:1124-32.

5. Gonçalves AV, Makuch MY, Setubal MS, Barros NF, Bahamondes L. A qualitative study on the practice of yoga for women with pain-associated endometriosis. J Altern Complement Med 2016; 22:977-82.

6. Roomaney R, Kagee A. Coping strategies employed by women with endometriosis in a public health-care setting. J Health Psychol 2016; 21:2259-68.

7. Jones G, Jenkinson C, Kennedy S. The impact of endometriosis upon quality of life: a qualitative analysis. J Psychosom Obstet Gynecol 2004; 25:123-33.

8. Denny E. Women's experience of endometriosis. J Adv Nurs 2004; 46:641-8.

9. Riazi H, Tehranian N, Ziaei S, Mohammadi E, Hajizadeh E, Montazeri A. Patients' and physicians' descriptions of occurrence and diagnosis of endometriosis: a qualitative study from Iran. BMC Womens Health 2014; 14:103.

10. Mayring P. Qualitative Inhaltsanalyse: Grundlagen und Techniken. 12th Ed. Weinheim: Beltz; 2015.

11. Sourial S, Tempest N, Hapangama DK. Theories on the pathogenesis of endometriosis. Int J Reprod Med 2014; 2014:1-9.

12. Burney RO, Giudice LC. Pathogenesis and pathophysiology of endometriosis. Fertil Steril 2012; 98:511-9.

13. Lebovic DI, Mueller MD, Taylor RN. Immunobiology of endometriosis. Fertil Steril 2001; 75:1-10.

14. Nouri K, Ott J, Krupitz B, Huber JC, Wenzl R. Family incidence of endometriosis in first-, second-, and third-degree relatives: case-control study. Reprod Biol Endocrinol 2010; 8:1-7.

15. Simpson JL, Elias S, Malinak LR, Buttram VC. Heritable aspects of endometriosis. I. Genetic studies. Am J Obstet Gynecol 1980; 137:327-31.

16. Chiantera V, Abesadze E, Mechsner S. How to understand the complexity of endometriosisrelated pain. J Endometr Pelvic Pain Disord 2017; 9:30-8.

17. Johnson NP, Hummelshoj L. Consensus on current management of endometriosis. Hum Reprod 2013; 28:1552-68. 
18. International Association for the Study of Pain. IASP terminology. https://www.iasp-pain.org/ Education/Content.aspx? ItemNumber $=1698$ (accessed on 29/Jun/2020).

19. Brook P, Connell J, Pickering T, editors. Oxford handbook of pain management. Oxford: Oxford University Press; 2011.

20. Merskey H, Bogduk N, editors. Classification of chronic pain, descriptions of chronic pain syndromes and definitions of pain terms. 2nd Ed. Washington DC: IASP Press; 1994.

21. Specht-Tomann M, Sandner-Kiesler A. Schmerz, wie können wir damit umgehen? Ostfildern: Patmos-Verlag der Schwabenverlag AG; 2005.

22. Bitzer J, Tschudin S, Frey B, Alder J. Psychosomatische Betreuung von Patientinnen mit Endometriose. J Gynakol Endokrinol 2008; 2:54-7.

23. Greene R, Stratton P, Cleary SD, Ballweg ML, Sinaii N. Diagnostic experience among 4,334 women reporting surgically diagnosed endometriosis. Fertil Steril 2009; 91:32-9.

24. Tully A. Stress, sources of stress and ways of coping among psychiatric nursing students. J Psychiatr Ment Health Nurs 2004; 11:43-7.

25. Hudelist G, Fritzer N, Thomas A, Niehues C, Oppelt P, Haas D, et al. Diagnostic delay for endometriosis in Austria and Germany: causes and possible consequences. Hum Reprod 2012; 27:3412-6.

26. Hadfield R, Mardon H, Barlow D, Kennedy S. Delay in the diagnosis of endometriosis: a survey of women from the USA and the UK. Hum Reprod 1996; 11:878-80.

27. Husby GK, Haugen RS, Moen MH. Diagnostic delay in women with pain and endometriosis. Acta Obstet Gynecol Scand 2003; 82:649-53.

28. Santos TMV, Pereira AMG, Lopes RGC, Depes DDB. Lag time between onset of symptoms and diagnosis of endometriosis. Einstein (São Paulo) 2012; 10:39-43.

29. Bento PASS, Moreira MCN. Quando os olhos não veem o que as mulheres sentem: a dor nas narrativas de mulheres com endometriose. Physis (Rio J.) 2018; 28:e280309.

30. Nnoaham KE, Hummelshoj L, Webster P, d'Hooghe T, Nardone FC, Nardone CC, et al. Impact of endometriosis on quality of life and work productivity: a multicenter study across ten countries. Fertil Steril 2011; 96:366-373.e8.

31. Moradi M, Parker M, Sneddon A, Lopez V, Ellwood D. Impact of endometriosis on women's lives: a qualitative study. BMC Womens Health 2014; 14:123.

32. Brucker C. Symptome und diagnostik. In: Steck T, Felberbaum R, Küpker W, Brucker C, Finas D, editors. Endometriose. Entstehung, Diagnose, Verlauf und Therapie. Vienna: Springer; 2004. p. 81-101.

33. Baldi A, Campioni M, Signorile PG. Endometriosis: pathogenesis, diagnosis, therapy and association with cancer. Oncol Rep 2008; 19:843-6.
34. Mechsner S. Endometriose: eine oft verkannte Shmerzerkrankung. Schmerz 2016; 30:477-90.

35. Cox H, Henderson L, Wood R, Cagliarini G. Learning to take charge: women's experiences of living with endometriosis. Complement Ther Nurs Midwifery 2003; 9:62-8.

36. Ott J, Nouri K, Hrebacka D, Gutschelhofer S, Huber JC, Wenzl R. Endometriosis and nutrition - recommending a Mediterranean diet decreases endometriosis-associated pain : an experimental observational study. J Aging Res Clin Pract 2012; 1:162-6.

37. Karlsson JV, Patel H, Premberg A. Experiences of health after dietary changes in endometriosis: a qualitative interview study. BMJ Open 2020; 10:e032321.

38. Deguara CS, Pepas L, Davis C. Does minimally invasive surgery for endometriosis improve pelvic symptoms and quality of life? Curr Opin Obstet Gynecol 2012; 24:241-4.

39. Fauconnier A, Fritel X, Chapron C. Relations entre endométriose et algie pelvienne chronique: quel est le niveau de preuve? Gynecol Obstet Fertil 2009; 37:57-69.

40. Witzel A. Das problemzentrierte Interview. Forum Qual Sozialforsch 2000; 1:22. http:// www.qualitative-research.net/index.php/fqs/ article/view/1132/2519.

41. Misoch S. Qualitative interviews. Berlin: De Gruyter; 2015.

42. Battacchi M, Suslow T, Renna M. Emotion und sprache: zur definition der emotion und ihren beziehungen zu kognitiven prozessen, dem gedächtnis und der sprache. 2nd Ed. Bern: Peter Lang GmbH; 1997.

43. Mayer I, Kahr M. Endometriose Vereinigung Austria (EVA). https://www.eva-info.at/impressum/ (accessed on 29/Jun/2020).

44. Przyborski A, Wohlrab-Sahr M. Qualitative Sozialforschung: ein Arbeitsbuch. 4th Ed. Berlin: De Gruyter Oldenburg; 2013.

45. The European Parliament; The Council of the European Union. Regulation (EU) 2016/679 of the European Parliament and of the Council of 27 April 2016 on the protection of natural persons with regard to the processing of personal data and on the free movement of such data, and repealing Directive 95/46/EC (General Data Protection Regulation). Official Journal of the European Union 2016; 4 may.

46. van der Zanden M, Teunissen DAM, van der Woord IW, Braat DDM, Nelen WLDM, Nap AW. Barriers and facilitators to the timely diagnosis of endometriosis in primary care in the Netherlands. Fam Pract 2020; 37:131-6.

47. O'Hara R, Rowe H, Fisher J. Self-management in condition-specific health: a systematic review of the evidence among women diagnosed with endometriosis. BMC Womens Health 2019; 19:80. 
48. Esterl M. Interaktion in der Arzt-Patientinnen-Beziehung beim Krankheitsbild Endometriose: eine qualitative Studie zur Interaktionswahrnehmung der Behandlerinnen hinsichtlich der Ärztinnen-Patientinnen-Beziehung in der medizinischen Versorgung. Psychother Forum 2015; 21:18-26.

49. Grundström H, Alehagen S, Kjølhede P, Berterö C. The double-edged experience of healthcare encounters among women with endometriosis: a qualitative study. J Clin Nurs 2018; 27:205-11.

50. Facchin F, Barbara G, Dridi D, Alberico D, Buggio L, Somigliana E, et al. Mental health in women with endometriosis: searching for predictors of psychological distress. Hum Reprod 2017; 32:1855-61.

51. Thomm M, editor. Schmerzmanagement in der Pflege. 2nd Ed. Berlin: Springer; 2016.

52. Overlach F. Sprache des Schmerzes - sprechen über Schmerzen: eine grammatisch-semantische und gesprächsanalytische Untersuchung von Schmerzausdrücken im Deutschen. v. 30. Berlin: Walter de Gruyter; 2008.
53. Moradi M, Parker M, Sneddon A, Lopez V, Ellwood D. The Endometriosis Impact Questionnaire (EIQ): a tool to measure the long-term impact of endometriosis on different aspects of women's lives. BMC Womens Health 2019; 19:64.

54. Jones G, Kennedy S, Barnard A, Wong J, Jenkinson C. Development of an endometriosis quality-of-life instrument. Obstet Gynecol 2001; 98:258-64.

55. Gilmour JA, Huntington A, Wilson HV. The impact of endometriosis on work and social participation. Int J Nurs Pract 2008; 14:443-8.

56. Rush G, Misajon R. Examining subjective wellbeing and health-related quality of life in women with endometriosis. Health Care Women Int 2018; 39:303-21. 


\section{Resumo}

O tema da endometriose e dor tem implicações relevantes para a saúde das mulheres. $O$ artigo procura contextualizar a experiência subjetiva e os efeitos da dor, os métodos para lidar com essas questões $e$ as necessidades das mulheres afetadas por essa condição na Áustria. Foi escolhida uma abordagem qualitativa para examinar esses temas. Foram realizadas entrevistas focadas em problemas com dez mulheres com história de endometriose. Após a transcrição do material, foi realizada a análise qualitativa do conteúdo. Assim, os achados são retratados com o uso de categorias relacionadas ao conteúdo. Os resultados mostram que pensamentos e sentimentos negativos como medo, desesperança e raiva estão associados com a endometriose e dor. Além disso, são encontrados impactos e mudanças predominantemente negativos em vários domínios da vida, tais como o bem-estar e o estado psicológicos das mulheres afetadas, a atitude geral em relação à vida, parcerias, vida social, tempo de lazer e equilíbrio entre trabalho e vida pessoal. Tanto a medicina ocidental quanto os tratamentos da medicina complementar são utilizados no manejo da endometriose e da dor. $O$ apoio do círculo próximo de amigas e as trocas e interação com outras pessoas afetadas pela doença são vistos como extremamente úteis. Os médicos atendentes e as próprias pacientes e seus ambientes privados, sociais e laborais devem incentivar a comunicação aberta sobre a endometriose e a dor associada.

Endometriose; Dor; Pesquisa Qualitativa

\section{Resumen}

La endometriosis y su dolor asociado implican problemas profundos para la salud de las mujeres. El objetivo de este trabajo es identificar la experiencia subjetiva y los efectos del dolor, los métodos para tratarlos, así como las necesidades de las mujeres afectadas en Austria. Para el examen de los temas mencionados anteriormente, se eligió un enfoque de investigación cualitativo. Las entrevistas enfocadas en los problemas se realizaron con diez mujeres que sufrían endometriosis. Tras la transcripción material de los datos, el análisis se realizó usando un análisis cualitativo de contenido. Por lo tanto, los resultados se describen usando categorías relacionadas con el contenido. Los resultados muestran que los pensamientos negativos $y$ los sentimientos como miedo, desesperación, y enfado están conectados con la endometriosis y el dolor. Además, predominantemente se encontraron impactos negativos y cambios en varias áreas de la vida, tales como: bienestar, psique de quienes se veían afectadas, su actitud ante la vida en general, relaciones, vida social, equilibrio entre tiempo de ocio y trabajo. Para enfrentarse a la endometriosis $y$ el dolor, se utilizan tratamientos biomédicos occidentales, así como medicina complementaria. El apoyo del círculo íntimo de los afectados, como son los amigos, así como el intercambio e interacción con otras personas afectadas por la enfermedad parecen ser muy útiles. Ir al médico, el entorno privado, social y laboral de las pacientes, así como ellas mismas, deben estar y ser animadas para una comunicación abierta sobre la endometriosis y el dolor relacionado con la misma.

Endometriosis; Dolor; Investigación Cualitativa
Submitted on $29 / \mathrm{Jul} / 2020$

Final version resubmitted on 14/Jul/2021

Approved on 29/Jul/2021 